\title{
Diverse Locations and a Long History: Historical Context for Urban Leopards (Panthera pardus) in the Early Anthropocene From Seoul, Korea
}

\section{OPEN ACCESS}

Edited by:

MKS Pasha,

WWF, Singapore

Reviewed by:

Yash Veer Bhatnagar,

Nature Conservation Foundation, India

Jennifer Bond

Charles Sturt University, Australia

*Correspondence:

Joshua Powell

joshua.powell.19@ucl.ac.uk

Specialty section:

This article was submitted to

Human-Wildlife Dynamics,

a section of the journa

Frontiers in Conservation Science

Received: 27 August 2021

Accepted: 11 October 2021

Published: 15 November 2021

Citation:

Powell J, Axmacher JC, Linnell JDC and Durant SM (2021) Diverse

Locations and a Long History:

Historical Context for Urban Leopards (Panthera pardus) in the Early

Anthropocene From Seoul, Korea.

Front. Conserv. Sci. 2:765911.

doi: 10.3389/fcosc. 2021.765911

\begin{abstract}
Joshua Powell ${ }^{1,2,3,4 *}$, Jan C. Axmacher ${ }^{2,5}$, John D. C. Linnell ${ }^{6,7}$ and Sarah M. Durant ${ }^{1}$
1 Institute of Zoology, Zoological Society of London, London, United Kingdom, ${ }^{2}$ Department of Geography, University College London, London, United Kingdom, ${ }^{3}$ College of Veterinary Medicine, Seoul National University, Seoul, South Korea, ${ }^{4}$ Tiger and Leopard Conservation Fund in Korea, Seoul, South Korea, ${ }^{5}$ Faculty of Environmental and Forest Sciences, Agricultural University of Iceland, Reykjavik, Iceland, ${ }^{6}$ Department of Terrestrial Biodiversity, Norwegian Institute for Nature Research, Trondheim, Norway, ${ }^{7}$ Department of Forestry and Wildlife Management, Inland Norway University of Applied Sciences,

Evenstad, Norway
\end{abstract}

While the urban landscapes of the early Anthropocene may appear hostile to large carnivores, humans and leopards (Panthera pardus) are known to co-inhabit major urban centres like Mumbai (India), Nairobi (Kenya) and Johannesburg (South Africa). We provide evidence that the presence of leopards in urban landscapes is not, however, a new phenomenon and has occurred repeatedly over the early history of the Anthropocene. Using records of Amur leopards (P. p. orientalis) in Seoul, Korea, at the end of the 19th century, a capital city and major urban centre with a high human population density, we explore socio-cultural, political and ecological factors that may have facilitated human-leopard co-occurrence in an urban landscape and the factors that eventually led to the leopards' extirpation. We suggest that, in the absence of unsustainable levels of persecution by humans, leopards are able to persist in urban landscapes which contain small patches of dense vegetation and have sufficient alternative food supplies. In light of the continued expansion of urban landscapes in the 21st century and increasing conservation focus on the presence of large carnivore populations there, this paper provides historical context to human co-existence with leopards in urban landscapes during the Anthropocene-and what we can learn from it for the future.

Keywords: leopard, big cats, cities, Seoul, urban carnivore, Panthera pardus, Korea (Joseon), historical mammal distributions

\section{INTRODUCTION}

An exact starting date for the Anthropocene, a term used to describe a human-dominated geological epoch that encompasses the present day, remains elusive (see, for example, Crutzen and Stoermer, 2000; Glikson, 2013; Zalasiewicz et al., 2015). Steffen et al. (2011) proposed that the early history of the Anthropocene has occurred in two distinct stages, the first of which started with the spread of the Industrial Revolution in the early 1800s, the second with the Great Acceleration of the mid-20th century. Lewis and Maslin (2015) have subsequently shown that an earlier starting date of A.D. 1610 can be justified. During this time period, a series of wide-reaching 
Anthropogenic changes to the natural environment have occurred, including the rapid expansion of urban landscapes (Butler, 2018).

Urban landscapes are characterised by extremely high levels of human modification (McKinney, 2006). The presence in such environments of large carnivores, which are usually associated with wild lands, extremely large home range requirements (Carbone and Gittleman, 2002) and the availability of wild, large vertebrate prey (Carbone et al., 2007), appears counterintuitive. A number of recurrent features of urban landscapes would seem to present particular obstacles: the fragmentation or removal of natural habitat remnants; the removal of large-bodied wild prey species; the presence of artificial light sources at night; the densely-packed construction of buildings and other artificial structures; and extremely high densities of Homo sapiens.

Despite the seeming hostility of urban environments, several large carnivore species can persist and even thrive there. For example, spotted hyena (Crocuta crocuta) occur in both urban and peri-urban landscapes in Ethiopia (Kruuk, 2002; Yirga et al., 2015); mountain lions (Puma concolor) have been welldocumented in urban California, USA (Riley et al., 2014); coyotes (Canis latrans) now occur in cities across the USA (Grinder and Krausman, 2001; Bateman and Fleming, 2012); and American black bears (Ursus americanus) forage in a range of urban environments in the western USA (Beckmann and Lackey, 2008; Lewis et al., 2015).

The leopard (Panthera pardus) is another large carnivore that is known to be capable of adapting to life in urban environments (Jacobson et al., 2016). While considerably larger than most other truly urban carnivores (Bateman and Fleming, 2012), the leopard shares certain characteristics with its fellow city-dwellers, notably a wide-ranging diet (Hayward et al., 2006; Athreya et al., 2016) and behavioural plasticity (Jacobson et al., 2016). These characteristics allow leopards to survive in urban landscapes, and to access alternative food sources, such as stray dogs, which may be present in high densities (Punjabi et al., 2012; Athreya et al., 2016).

Extant urban leopard populations have been recorded in Mumbai, India (Odden et al., 2014); Nairobi, Kenya (Landy et al., 2018); and Johannesburg, South Africa (Kuhn, 2014). While poorly documented in the scientific literature, leopards are also known to exist in other urban landscapes across India, including Jhalana, Guwahati, Surat, Gurugram, Shimla, Darjeeling and Bangalore (Athreya, pers. com., 2020), Dehradun (Anonymous, 2007) and Hyderabad (Breitenmoser and Breitenmoser, 2008). They are also known from cities in southern and eastern Africa, including Dar es Salaam and Arusha in Tanzania (Durant, pers. com., 2020); Cape Town and Pretoria in South Africa (Myers, 1976); and the outskirts of Gaborone in Botswana (Klein, pers. com., 2020).

While there has been increasing interest in the presence of urban carnivore populations (Gehrt et al., 2010), the ecosystem services they provide (Braczkowski et al., 2018) and the nature of their interactions with human populations (Bhatia et al., 2013), there has been little scholarship dedicated to examining the occurrence, or persistence, of urban leopards outside of contemporary Mumbai, Nairobi and Johannesburg. There is particularly little understanding about the historical dimension of leopard occurrence in urban landscapes of the Anthropocene. This is important, because better understanding the socioecology of large carnivores in urban landscapes over time and the conditions that either facilitate their persistence or lead to their extirpation, may be able to help inform future conservation (Rick and Lockwood, 2012).

Historical ecology, a field which utilises historic sources and datasets to study ecosystems through time, can be used to provide valuable insight into the past distribution of species (Oates and Rees, 2013; Turvey et al., 2015) and historical interactions between humans and wildlife populations (Balee, 2006; Szabo and Hedl, 2011). In this short study, we use historical ecology to examine the presence of a large carnivore in an urban landscape during the late 19th Century, using the example of Amur leopards (P. p. orientalis) in Seoul, Korea.

Seoul was already a major urban centre by the early Anthropocene. Contemporary estimates varied, but by the turn of the 20th century the city was thought to have a human population of $\sim 250,000$ (Hatch, 1904), or 300,000 (Veitch, 1896), inhabitants. Unlike its current layout, late 19th and early 20th century Seoul was confined to the north of the Han River, between the mountains of Namsan and Baekaksan. This area of $16.7 \mathrm{~km}^{2}$ was fully enclosed by a $6-8 \mathrm{~m}$ high city wall, with a potential human population density of at least $14,970 / \mathrm{km}^{2}$, comparable to the current population density of Jakarta, Indonesia. Seoul had been the national capital since A.D. 1394 and five royal palaces within the city featured large, landscaped gardens (Hong, 2018), each enclosed by a further high wall; for example, the wall surrounding Gyeongbokgung was 6 $\mathrm{m}$ high.

The historical occurrence of leopards in Seoul is virtually unheard of in the English-language conservation literature (for example, Jacobson et al., 2016). However, using early Western accounts of Seoul in the late 19th century to corroborate Korean records of big cats provided by Hong (2018) from the Joseon Wangjo Sillok (Hanja: 王朝實錄, Hangul: 조선왕조실록), a detailed 14 th -19 th century record of the reign of Korea's Joseon dynasty (A.D. 1392-1897) kings, and the Seungjeongwon ilgi (Hanja: 承政院 日記, Hangul: 승정원 일기), the journal of the Korean royal secretariat, we demonstrate that leopards were present in this urban landscape during the late 19th century, investigate the conditions that may have allowed leopards to persist there, and highlight factors that likely contributed to their extirpation.

\section{METHOD}

We searched for historical accounts of leopards in Seoul, Korea, from published books, field notes, correspondence, and private journals of Western researchers, travellers and residents in Seoul in the late 19th and early 20th centuries. As well as conducting a review of the published scientific literature, we searched the archives of the Royal Geographical Society (with IBG), Zoological Society of London, Linnean Society of London, SOAS University of London (the School of Oriental and African Studies) and the British Library's Asian and African Reading Room, as well as 
publicly available records of relevant museums in Seoul (Seoul Museum of History; National Museum of Korea). We also searched for Korean records from the Joseon Wangjo Sillok and the Seungjeongwon ilgi, as per Hong (2018). In archive databases, we searched for the keywords: leopard, tiger (Panthera tigris), (due to the historical use of the same Korean characters for both felids), big cat, Seoul, Hanyang (a historical name for Seoul), the alternative spellings of Korea and Corea, and Joseon (the ruling Korean dynasty of the 19th century). As we did not find any records after A.D. 1900, we focussed our search on the period between A.D. 1870 and A.D. 1900, 3 decades which encompass the opening of Korea's borders to international trade and therefore provide the first regularly available foreign accounts of the wildlife of Korea.

These historical records present an under-utilised and potentially valuable source of data for the study of historical wildlife populations. However, there are some important limitations to take into account. Historical records of rare animals may be based on hearsay, which may lead to the reporting of species that were not actually present; doublereporting of individual animals if a single account is reported by numerous sources; or simply confusion between which species are present. In this, some accounts may be considered more reliable than others, though it is important to note that many of the records we found were by well-travelled and educated individuals, including politicians, teachers, doctors and hunters, many of whom could clearly distinguish between a leopard and other felids. In order to communicate the reliability of each sighting, we assigned each report with a classification of confirmed, where the sighting was a first-hand sighting of a leopard or where the author reported that a leopard was killed; probable, where a big cat was reported and sufficient evidence was provided by the author to suggest classification as a leopard, or where a second-hand account of a leopard being sighted was reported; or possible, where an account refers to a big cat being sighted, but insufficient evidence is provided to classify the sighting to a species level. Records which did not directly refer to a big cat being sighted were discounted.

It is also important to acknowledge that historical records may be damaged, destroyed or lost over time, for example during the Korean War (A.D. 1950-53). In addition, records from personal correspondence may be particularly difficult for the environmental historian to locate (for example, if they are held in private collections and have not been digitised). Though extensive, the archives we searched will therefore likely only represent a fraction of the total available material held in public and private collections which detail accounts of Korea in the late 19th century. Further work, particularly utilising archives in languages other than Korean and English, may therefore be able to shed light on additional relevant source material.

\section{RESULTS}

We present twelve corroborating records of urban leopards in Seoul between A.D. 1870 and 1900 in Table 1. Two of these records are Korean records from the Seungjeongwon ilgil, where, due to the historical use of the same Korean characters, 호랑이 (horangee), to describe the tiger and leopard, we can only confirm that the authors are referring to one of these two Panthera species. However, given the presence of 6-8 m high city walls around Seoul and the specific identification of leopards in sources from Western travellers, we strongly suspect that these "horangee" records actually refer to leopards rather than tigers.

To provide context to these sightings, a contemporary map of Seoul, produced between 1890 and 1897, is provided in Figure 1. The locations of potential leopard sightings, where recorded, are marked in red. These are concentrated around the royal palaces and foreign embassies, areas of the city that contained patches of natural vegetation and water sources such as ponds, had some restrictions on public access, and were relatively close to the city wall. However, they also correspond to the areas of Seoul which early Western visitors were most likely to visit. Figure 2, a photograph taken around 1902 close to the location of one of the reported sightings, illustrates the high level of urban development and density of dwellings inside the city at the time.

\section{DISCUSSION}

Our findings support the claim by Hong (2018) that big cats were historically present in Seoul and provide evidence of Amur leopards specifically within the city walls in the late Joseon dynasty (A.D. 1870-1900). This example illustrates that leopards have occurred in urban landscapes since the early history of the Anthropocene, well-before the advent of modern environmentalism. Given the contrasting economic, socio-cultural and political situations present in 19th century Seoul and contemporary Mumbai, Nairobi and Johannesburg, it is also clear that leopards are capable of adapting to a wide range of urban landscapes.

There are a number of important ecological similarities, however, between 19th century Seoul and contemporary urban centres inhabited by leopard populations. It therefore appears that leopards may potentially require certain ecological conditions to be present in order to persist in urban landscapes. The first is the presence of alternative food supplies in the urban landscape. Some contemporary accounts speculated that leopards in 19th century Seoul may have preyed on the city's stray dog population (Cavendish, 1894), which would mirror the known make-up of the leopard's diet in contemporary Mumbai (Athreya et al., 2016). These were not, however, the only potential food sources available in the city. Domestic pigs also roamed Seoul's maze of narrow residential streets (Veitch, 1896), while Gyeongbokgung Palace is known to have had a population of tame deer within its grounds (Seungjeongwon ilgi, 1893).

Another important ecological similarity is the availability of natural vegetation patches. An important feature for the persistence of other urban carnivores (Baker and Harris, 2007), for leopards these patches provide shelter during the day. Sanjay Gandhi National Park in Mumbai performs this role, as does Nairobi National Park neighbouring Nairobi. In Seoul, the royal palaces and their extensive gardens seem to have provided this 
TABLE 1 | Records of leopards in Seoul in the late 19th century by Western residents and travellers, and the Seungjeongwon ilgi.

\begin{tabular}{|c|c|c|c|}
\hline $\begin{array}{l}\text { Date and location of } \\
\text { sighting }\end{array}$ & Source & Description of sighting & Quality of record \\
\hline $\begin{array}{l}\text { 27th November } 1871 \text {, } \\
\text { Changdeokgung Palace }\end{array}$ & $\begin{array}{l}\text { Seungjeongwon ilgi (Seungjeongwon ilgi, } \\
1871 \text { ) }\end{array}$ & $\begin{array}{l}\text { Killed one "horangee" in Changdeokgung } \\
\text { Palace. }\end{array}$ & Possible \\
\hline $\begin{array}{l}\text { 1886, winter Russian } \\
\text { Embassy and } \\
\text { Gyeonghuigung Palace }\end{array}$ & Antoinette Sontag (Neff, 2020) & $\begin{array}{l}\text { Direct sighting of leopard by author. } \\
\text { Tracked to abandoned Gyeonghuigung } \\
\text { Palace. }\end{array}$ & Confirmed \\
\hline $\begin{array}{l}\text { 1880-1892, winter Embassy } \\
\text { quarter }\end{array}$ & George W. Gilmore (Gilmore, 1892) & $\begin{array}{l}\text { Leopard shot and another seen several } \\
\text { times within a hundred yards. }\end{array}$ & Confirmed \\
\hline $\begin{array}{l}\text { 1880s, either } \\
\text { Gyeonghuigung or } \\
\text { Changdeokgung Palace }\end{array}$ & $\begin{array}{l}\text { Arnold Henry Savage Landor (Landor, } \\
\text { 1895) }\end{array}$ & $\begin{array}{l}\text { Alfred Burt stripling and assistant tracked a } \\
\text { big cat (originally thought to be a tiger) into } \\
\text { abandoned palace sewers. Leopard killed. }\end{array}$ & Confirmed \\
\hline c. 1888, Russian Embassy & $\begin{array}{l}\text { Dr. Lillias H. Underwood (Underwood, } \\
\text { 1904) }\end{array}$ & $\begin{array}{l}\text { Author reported first-hand sighting of a } \\
\text { tiger on arrival to Seoul. Leopard seen at } \\
\text { Russian Embassy. }\end{array}$ & Confirmed \\
\hline $\begin{array}{l}\text { 1891, winter, Russian } \\
\text { Embassy }\end{array}$ & $\begin{array}{l}\text { Captain A. E. J. Cavendish (Cavendish, } \\
\text { 1894) }\end{array}$ & $\begin{array}{l}\text { Reported leopard sighting at Russian } \\
\text { Embassy and noted this was a regular } \\
\text { occurrence every winter. }\end{array}$ & Probable \\
\hline $\begin{array}{l}\text { 12th December 1893, } \\
\text { Gyeonbokgung Palace }\end{array}$ & $\begin{array}{l}\text { Seungjeongwon ilgi (Seungjeongwon ilgi, } \\
\text { 1893) }\end{array}$ & $\begin{array}{l}\text { Gyeongbokgung Palace evidence of at } \\
\text { least one "horangee" for } 5 \text { days. Hunters } \\
\text { unsuccessful in tracking it down. } \\
\text { Suspected leopard. }\end{array}$ & Possible \\
\hline c.1892-3, Seoul & George Nathaniel Curzon (Curzon, 1896) & $\begin{array}{l}\text { Describes leopards sometimes entering } \\
\text { Seoul during the winter months. }\end{array}$ & Probable \\
\hline $\begin{array}{l}\text { c. } 1894 \text {, Changdeokgung } \\
\text { Palace }\end{array}$ & $\begin{array}{l}\text { Dr. Lillias H. Underwood (Underwood, } \\
\text { 1904) }\end{array}$ & $\begin{array}{l}\text { Author reports hearsay that "leopards and } \\
\text { tigers" sleeping at Changdeokgung } \\
\text { Palace, which is overgrown. }\end{array}$ & Probable \\
\hline $\begin{array}{l}\text { Early } 1890 \text { 's, Seoul city } \\
\text { walls }\end{array}$ & $\begin{array}{l}\text { Arnold Henry Savage Landor (Landor, } \\
\text { 1895) }\end{array}$ & $\begin{array}{l}\text { Describes "tigers" entering Seoul, over the } \\
\text { city walls. Author can distinguish leopards } \\
\text { and tigers, but likely a second-hand } \\
\text { account. }\end{array}$ & Possible \\
\hline Pre-1898, Seoul & Isabella Lucy (Bird) Bishop (Bishop, 1898) & $\begin{array}{l}\text { Reports that leopards are present in large } \\
\text { numbers in Korea and have been shot } \\
\text { within the walls of Seoul. }\end{array}$ & Confirmed \\
\hline $\begin{array}{l}\text { 1896-1904, old western } \\
\text { palace (likely Deoksugung } \\
\text { Palace) }\end{array}$ & William Franklin Sands (Sands, 1930) & $\begin{array}{l}\text { Records that the abandoned palace is } \\
\text { sometimes the haunt of a leopard or wolf. }\end{array}$ & Probable \\
\hline
\end{tabular}

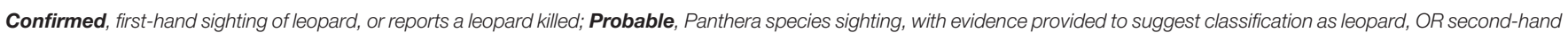
account of leopard sighting; Possible, Account refers to Panthera species (either tiger or leopard), but insufficient evidence provided to classify to species level.

function, despite being far smaller than either national park (the largest royal palace, Changdeokgung, covered just $\sim 45 \mathrm{ha}$ ), with a number of reports specifically identifying leopards in or around royal palaces (for example, Gilmore, 1892; Landor, 1895; Sands, 1930).

The use by leopards of Seoul's royal palace grounds was facilitated by political conditions in Korea in the late 19th century. Hong (2018) believed that damage to, or temporary abandonment of, royal palaces in Seoul created conditions favourable to their occupation by big cats. Gyeongbokgung Palace had been derelict for almost 3 centuries when it was rebuilt in 1867 and several of the other royal palaces in Seoul were temporarily abandoned in the late-1800s (Gyeonghuigung and Changdeokgung, later followed by Gyeongbokgung). As these were royal sites associated with a sitting dynasty, it is unlikely that the abandoned palaces would have been occupied by other human inhabitants, creating patches of natural vegetation without regular human disturbance inside a denselypopulated city.

The practise of not cutting trees on the edge of Seoul meant that good forest cover also remained in the landscape immediately surrounding the city in the late 19th century (Walton, 1900). The leopard is a wide-ranging and highly mobile large carnivore that would certainly have been capable of utilising different habitats across the wider landscape in which Seoul occurred. Curzon (1896) believed that leopards were particularly likely to be seen in the city core during the winter. A similar pattern was observed in Russia by Goodrich et al. (2011) for tigers, which were more likely to enter villages in winter months. The authors theorised that this was due to increased physical stress and lower prey availability during the cold winters of north-east Asia. The presence of forest cover on Seoul's boundary would have allowed leopards to approach the city walls at night undetected. 


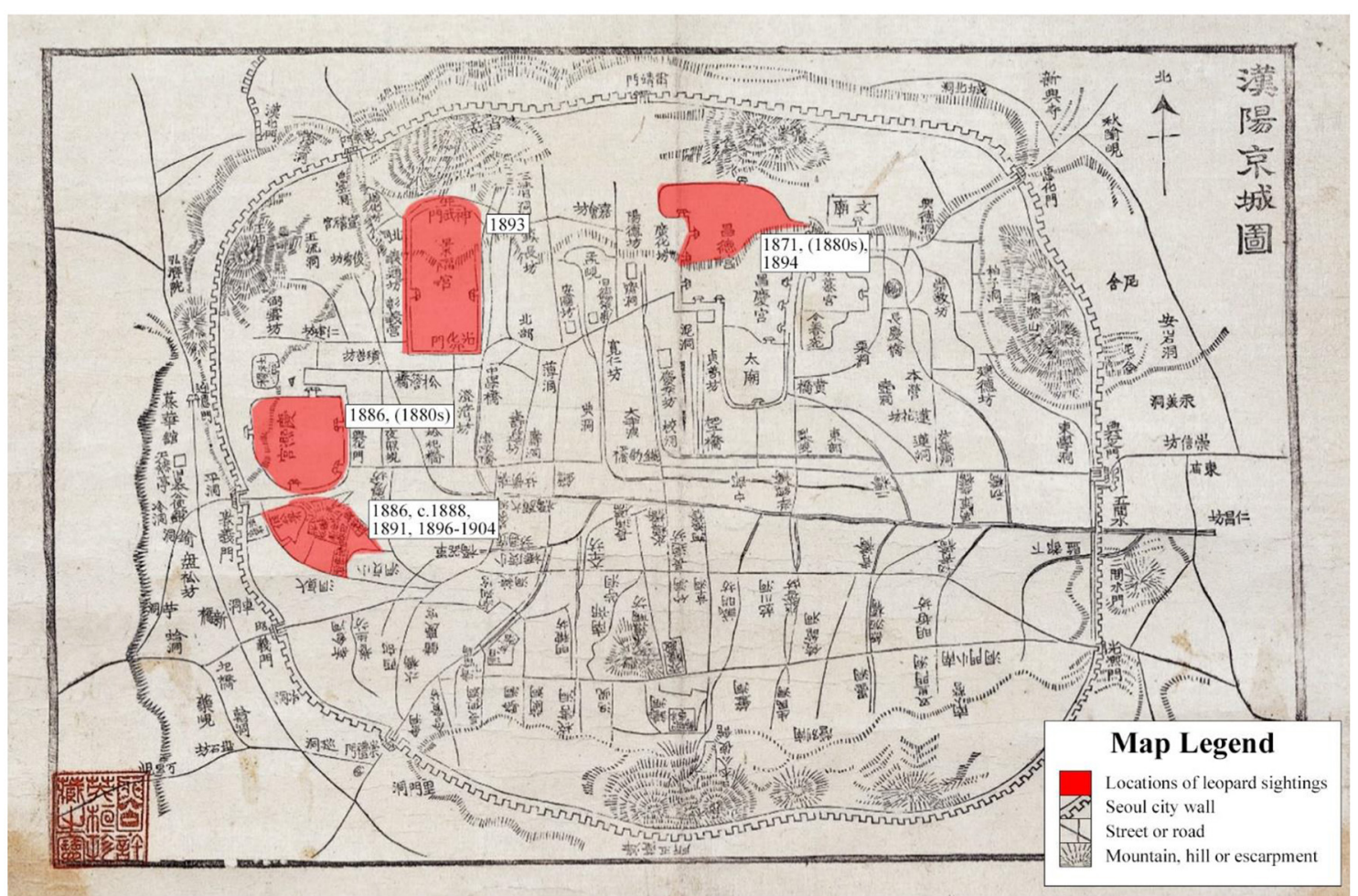

FIGURE 1 | Historical map of Seoul, produced between A.D. 1890-1897. Reproduced courtesy of Seoul Museum of History. Locations, where recorded, of potential leopard sightings (1870-1900) marked in red, with date of sighting provided.

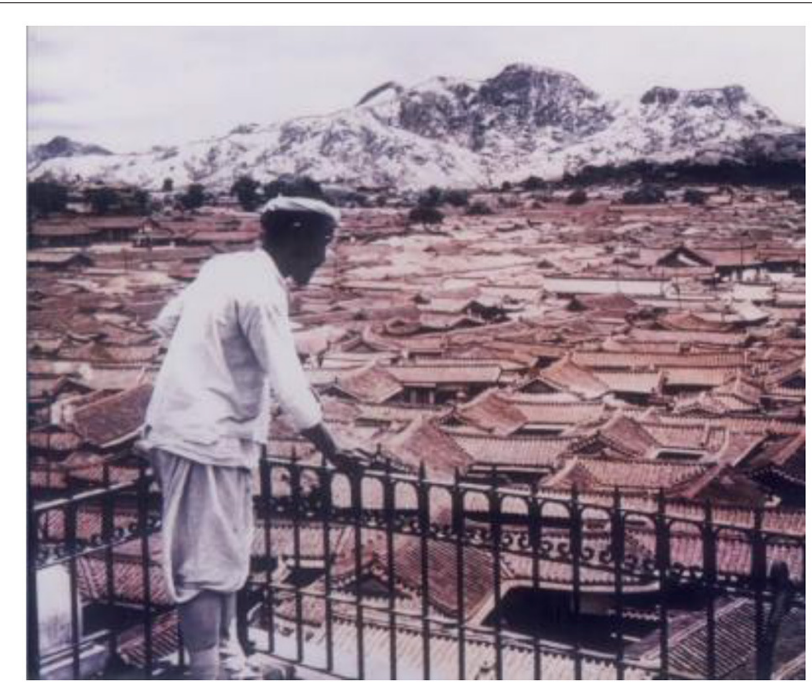

FIGURE 2 | Photograph of Seoul from the Sontag Hotel, c. 1902, close to the location of Antoinette Sontag's rooftop sighting of an urban leopard.

Photographer unknown. Reproduced courtesy of JoongAng llbo. Note the high level of urban development and the density of dwellings.

Socio-cultural factors likely also played an important role in facilitating human-leopard coexistence in this urban landscape. Contemporary accounts regularly recorded a widespread and intense fear of big cats in Joseon dynasty Korea, which extended to an unwillingness to travel at night for fear of them (Curzon, 1896; Bishop, 1898), reducing the likelihood of encounters between humans and leopards. Even in the core of Seoul, the maze of narrow, unlit streets (see Veitch, 1896) would have posed little obstacle for elusive leopards to navigate undetected at night.

The history of leopards in Seoul should also serve as a cautionary tale for contemporary large carnivore conservation. It illustrates that the relationship between large carnivores and humans in urban landscapes may change rapidly, sometimes due to unpredictable social, economic, or political factors, and where this leads to an increase in targeted killing of large carnivores it can result in the swift extirpation of even the most adaptable species. As in Japan, where the impact of political changes on the grey wolf (Canis lupus) populations of Honshu and Hokkaido has been well-documented (Walker, 2008), the late 19th century was a period of unprecedented political change and social upheaval in Korea (Underwood, 1904; Allen, 1908). Some early Western visitors to Korea carried firearms and were petitioned, or successfully hired, to kill big cats, including in Seoul (see, for example, Campbell, 1892; Landor, 1895). Large quantities of big cat skins, including leopard, were already being exported from Incheon, the closest port to Seoul, by 1887 (Seeley and Skabelund, 2015). The political changes sweeping through the country also resulted in alterations to the vegetation patches that had been present in the city; the formerly abandoned Gyeonghuigung Palace was converted into military barracks in 1896 (Sil, 1896). 
We know of no confirmed written records of leopards in Seoul after 1898 and we suspect that by the 20th century leopards were likely already extirpated from the immediate Seoul area. Although the leopard persisted in South Korea into the second half of the 20th century in remote mountainous regions, with the colonisation of Joseon dynasty Korea by Japan in 1910 and the introduction of an "eradication programme for harmful animals" (in Japanese: 害獸驅除事業), which included leopards (Seeley and Skabelund, 2015), there would have been little opportunity for a leopard population to re-establish in the landscape surrounding the capital.

Leopards were certainly not the only big cat found in the Seoul area. Indeed, the last reliable record of a big cat in the wider landscape was of an Amur tiger that was shot by hunters in 1913 on the slopes of Namsan, which marked the city's southern border and was dissected by the city wall. However, unlike the leopard, it is more difficult to state with any certainty that tigers were actually present inside the city during the time period under consideration. There is one record that a "horangee" was killed in the grounds of Changdeokgung Palace in 1871 (Seungjeongwon ilgi, 1871), but given the difficulty of separating between historical Korean records of leopards or tigers, we can only conclude that a big cat was killed. This is perhaps not unexpected. Ambiguity in distinguishing between leopard and tigers is a common issue in present day India among rural people (Athreya et al., 2018; Dhee et al., 2019; Nair et al., 2021). The reports we have refer to big cats in locations that would more commonly be associated with leopards, for example on rooftops and behind high walls, with at least one instance of a British hunter being employed to track down an urban "tiger" only to discover that the animal was a leopard (Landor, 1895).

The results of this short study show that the existence of leopards in urban landscapes is not a new phenomenon, but rather has occurred independently on multiple occasions throughout the Anthropocene, where ecological, socio-cultural and political conditions allowed. In the absence of human persecution, leopards seem able to persist in urban landscapes where there are alternative food sources and small patches of dense vegetation that can provide shelter during daylight. Maintaining these conditions may be key to the longterm persistence of leopard populations in urban landscapes where they are currently extant. However, when targeted human killing of leopards in urban landscapes increases, these populations can clearly be quickly extirpated. That the historic presence of leopards in urban landscapes in Korea has been overlooked by researchers outside of South Korea

\section{REFERENCES}

Allen, H. N. (1908). Things Korean: A Collection of Sketches and Anecdotes, Missionary and Diplomatic. New York, NY: Fleming H. Revell Company. doi: 10.5479/sil.50029.3908801650 0589

Anonymous (2007). Wildlife Health Service. Annual Report 2006-2007. Wildlife Institute of India. (see Jacobson et al., 2016) raises the intriguing possibility that leopards may have historically been more widespread in urban landscapes than the current scientific literature on felids suggests. Over the coming decades urban landscapes are likely to become increasingly widespread, with particularly high rates of urban growth predicted to occur in the 21st century in Asia and Africa (United Nations, 2015), continents which both support leopard populations. In light of this, further historical investigations would help us better understand the distribution and socio-ecological history of leopards and other large carnivores in urban landscapes over time, and the mechanisms that have supported their coexistence with human populations. This could provide important insights into the future persistence of these large carnivores in urban landscapes.

\section{DATA AVAILABILITY STATEMENT}

The original contributions presented in the study are included in the article, further inquiries can be directed to the corresponding author/s.

\section{AUTHOR CONTRIBUTIONS}

JP conceived of the study, collected the data, and wrote the manuscript with support from JA, JL, and SD. All authors provided critical feedback and helped shape the research, analysis, and writing of the final manuscript.

\section{FUNDING}

JP was funded by the Natural Environment Research Council [Grant Number NE/S007229/1]. JL was funded by the Research Council of Norway [Grant Number 251112]. This research was supported by Research England. UCL Open Access provided funding for open access publication fees. The funders had no role in study design, data collection and analysis, decision to publish, or preparation of the manuscript.

\section{ACKNOWLEDGMENTS}

The authors would like to thank Vidya Athreya, Peter Gerngross, Rebecca Klein, Karen Laurenson and Hans Bauer for their advice on urban leopard populations in India and Africa. They would also like to thank Sehee Park for her assistance with Korean language documents and Ji Hye Lee for her advice on Seoul in the Joseon Dynasty. pardus diet in a human-dominated landscape in western Maharashtra, India. Oryx 50, 156-162. doi: 10.1017/S003060531400 0106

Athreya, V., Pimpale, S., Borkar, A. S., Surve, N., Chakravarty, S., Ghosalkar, M., et al. (2018). Monsters or gods? Narratives of large cat worship in western India. Cat News 67, p. 23-26. 
Baker, P. J., and Harris, S. (2007). Urban mammals: what does the future hold? An analysis of the factors affecting patterns of use of residential gardens in Great Britain. Mamm. Rev. 37, 297-315. doi: 10.1111/j.1365-2907.2007.00102.x

Balee, W. (2006). The research program of historical ecology. Annu. Rev. Anthropol. 35, 75-98. doi: 10.1146/annurev.anthro.35.081705.123231

Bateman, P. W., and Fleming, P. A. (2012). Big city life: carnivores in urban environments. J. Zool. 287, 1-23. doi: 10.1111/j.1469-7998.2011.00887.x

Beckmann, J. P., and Lackey, C. W. (2008). Carnivores, urban landscapes, and longitudinal studies: a case history of black bears. Hum. Wildl. Confl. 2, 168-174.

Bhatia, S., Athreya, V., Grenyer, R., and Macdonald, D. W. (2013). Understanding the role of representations of human-leopard conflict in mumbai through media-content analysis. Conserv. Biol. 27, 588-594. doi: 10.1111/cobi.12037

Bishop, I. L. (1898). Korea and Her Neighbours. A Narrative of Travel, With an Account of the Recent Vicissitudes and Present Conditions of the Country. London: John Murray.

Braczkowski, A. R., O'Bryan, C. J., Stringer, M. J., Watson, J. E. M., Possingham, H. P., and Beyer, H. L. (2018). Leopards provide public health benefits in Mumbai, India. Front. Ecol. Environ. 16, 176-182. doi: 10.1002/fee.1776

Breitenmoser, U., and Breitenmoser, C. (2008). Stones and poison kill 21 straying leopards. Cat News, p. 49

Butler, D. R. (2018). Zoogeomorphology in the Anthropocene. Geomorphology 303, 146-154. doi: 10.1016/j.geomorph.2017.12.003

Campbell, C. W. (1892). A journey through North Korea to the Ch'ang-pai Shan. Proc. Royal Geogr. Soc. Mon. Rec. Geogr. 14, 141-161. doi: 10.2307/1801532

Carbone, C., and Gittleman, J. L. (2002). A common rule for the scaling of carnivore density. Science 295, 2273-2276. doi: 10.1126/science.1067994

Carbone, C., Teacher, A., and Rowcliffe, J. M. (2007). The costs of carnivory. PLoS Biol. 2:e22. doi: 10.1371/journal.pbio.0050022

Cavendish, A. E. J. (1894). Korea and the Sacred White Mountain: Being a Brief Account of a Journey in Korea in 1891. Together with an Account of an Ascent of the White Mountain. London: George Philip and Son.

Crutzen, P. J., and Stoermer, E. F. (2000). The Anthropocene. IGBP Glob. Chang. Newslett. 41, 17-18.

Curzon, G. N. (1896). Problems of the Far East. London: Archibald Constable and Co.

Dhee, A. V., Linnell, J. D. C., Shivakumar, S., and Dhiman, S. P. (2019). The leopard that learnt from the cat and other narratives of carnivore-human coexistence in northern India. People Nat. 1, 376-386. doi: 10.1002/pan3.10039

Gehrt, S. D., Riley, S. P. D., and Cypher, B. L. (2010). Urban Carnivores: Ecology, Conflict, and Conservation. Baltimore, MD: The John Hopkins University Press.

Gilmore, G. W. (1892). Korea from Its Capital: With a Chapter on Missions. Presbyterian Board of Publication and Sabbath-School Work.

Glikson, A. (2013). Fire and human evolution: the deep-time blueprints of the Anthropocene. Anthropocene 3, 89-92. doi: 10.1016/j.ancene.2014.02.002

Goodrich, J. M., Seryodkin, I., Miquelle, D. G., and Bereznukc, S. L. (2011). Conflicts between Amur (Siberian) tigers and humans in the Russian Far East. Biol. Conserv. 144, 584-592. doi: 10.1016/j.biocon.2010.10.016

Grinder, M. I., and Krausman, P. R. (2001). Home range, habitat use, and nocturnal activity of coyotes in an urban environment. J. Wildl. Manag. 65, 887-898. doi: $10.2307 / 3803038$

Hatch, E. F. G. (1904). Far Eastern Impressions. London: Hutchinson.

Hayward, M. W., Henschel, P., O'Brien, J., Hofmeyr, M., Balme, G., and Kerley, G. I. H. (2006). Prey preferences of the leopard (Panthera pardus). J. Zool. 270, 298-313. doi: 10.1111/j.1469-7998.2006.00139.x

Hong, H.-S. (2018). An emergence of tigers and leopards in the palace during the joseon period from the environmental historical perspective. J. Korean Inst. Tradit. Landsc. Arch. 36, 1-15. doi: 10.14700/KITLA.2018.36.3.001

Jacobson, A. P., Gerngross, P., Lemeris, Jr., J. R., Schoonover, R. F., Anco, C., et al. (2016). Leopard (Panthera pardus) status, distribution, and the research efforts across its range. PeerJ 4:e1974. doi: 10.7717/peerj.1974

Kruuk, H. (2002). Hunter and Hunted: Relationships Between Carnivores and People. Cambridge: Cambridge University Press. doi: $10.1017 /$ СBO9780511614996

Kuhn, B. F. (2014). A preliminary assessment of the carnivore community outside Johannesburg, South Africa. S. Afr. J. Wildl. Res. 44, 95-98. doi: $10.3957 / 056.044 .0106$
Landor, A. H. S. (1895). Corea or Cho-sen. The Land of the Morning Calm. London: William Heinemann.

Landy, F., Rodary, E., and Calas, B. (2018). Why "Did leopards kill humans in Mumbai but not in Nairobi? Wildlife management in and around urban national parks," in Urban National Parks to Natured Cities in the Global South, ed R. Landy (Gateway East: Springer), 157-179. doi: 10.1007/978-981-10-8462-1_7

Lewis, D. L., Baruch-Mordo, S., Wilson, K. R., Breck, S. W., Mao, J. S., and Broderick, J. (2015). Foraging ecology of black bears in urban environments: guidance for human-bear conflict mitigation. Ecosphere 6, 1-18. doi: 10.1890/ES15-00137.1

Lewis, S. L., and Maslin, M. A. (2015). Defining the Anthropocene. Nature 519, 171-180. doi: 10.1038/nature14258

McKinney, M. L. (2006). Urbanization as a major cause of biotic homogenization. Biol. Conserv. 127, 247-260. doi: 10.1016/j.biocon.2005.09.005

Myers, N. (1976). The Leopard Panthera pardus in Africa. IUCN Monograph No. 5. Morges: IUCN.

Nair, R., Dhee, P. O., Surve, N., Andheria, A., Linnell, J. D. C., and Athreya, V. (2021). Sharing spaces and entanglements with big cats: the warli and their Waghoba in Maharashtra, India. Front. Conserv. Sci. 2:683356. doi: $10.3389 /$ fcosc. 2021.683356

Neff, R. (2020, September 5). Leopards: a dangerous Korean luxury. The Korea Times.

Oates, L., and Rees, P. A. (2013). The historical ecology of the large mammal populations of Ngorongoro Crater, Tanzania, east Africa. Mamm. Rev. 43, 124-141. doi: 10.1111/j.1365-2907.2012.00211.x

Odden, M., Athreya, V., Rattan, S., and Linnell, J. D. C. (2014). Adaptable neighbours: movement patterns of GPS-collared leopards in human dominated landscapes in India. PLoS ONE 9:e112044. doi: 10.1371/journal.pone.0112044

Punjabi, G. A., Athreya, V., and Linnell, J. D. C. (2012). Using natural marks to estimate free-ranging dog Canis familiaris abundance in a MARK-RESIGHT framework in suburban Mumbai, India. Trop. Conserv. Sci. 5, 510-520. doi: $10.1177 / 194008291200500408$

Rick, T. C., and Lockwood, R. (2012). Integrating paleobiology, archeology, and history to inform biological conservation. Conserv. Biol. 27, 45-54. doi: 10.1111/j.1523-1739.2012.01920.x

Riley, S. P. D., Serieys, L. E. K., Pollinger, J. P., Sikich, J. A., Dalbeck, L., Wayne, R. K., et al. (2014). Individual behaviors dominate the dynamics of an urban mountain lion population isolated by roads. Curr. Biol. 24, 1989-1994. doi: 10.1016/j.cub.2014.07.029

Sands, W. F. (1930). Undiplomatic Memories. The Far East, 1896-1904. London: John Hamilton Ltd.

Seeley, J., and Skabelund, A. (2015). Tigers-real and imagined-in Korea’s physical and cultural landscape. Environ. Hist. 20, 475-503. doi: 10.1093/envhis/emv079

Seungjeongwon ilgi (1871, November 27). Journal of the Royal Secretariat. Seoul. Available online at: http://db.itkc.or.kr (accessed February 3, 2021).

Seungjeongwon ilgi (1893, December 12). Journal of the Royal Secretariat. Seoul. Available online at: http://db.itkc.or.kr (accessed February 3, 2021).

Sil, S. (1896). Private correspondence of Sally Sil to Joseph Sill, in Neff, R. (2012). Letters from Joseon. 19th Century Korea through the Eyes of an American Ambassador's Wife. Seoul: Seoul Selection.

Steffen, W., Grinevald, J., Crutzen, P., and McNeill, J. (2011). The Anthropocene: conceptual and historical perspectives. Philos. Trans. Royal Soc. A 369, 842-867. doi: 10.1098/rsta.2010. 0327

Szabo, P., and Hedl, R. (2011). Advancing the Integration of history and ecology for conservation. Conserv. Biol. 25, 680-687. doi: 10.1111/j.1523-1739.2011.01710.x

Turvey, S. T., Crees, J. J., and Di Fonzo, M. M. I. (2015). Historical data as a baseline for conservation: reconstructing long-term faunal extinction dynamics in Late Imperial-modern China. Proc. R. Soc. B 282:20151299. doi: 10.1098/rspb.2015.1299

Underwood, L. H. (1904). Fifteen Years Among the Top-Knots. Life in Korea. Boston, MA: American Tract Society.

United Nations (2015). World Urbanization Prospects: The 2014 Revision. United Nations Department of Economic and Social Affairs. 
Veitch, J. H. (1896). A Traveller's Notes. Notes of a tour through India, Malaysia, Japan, Corea, the Australian Colonies and New Zealand During the Years 1891-1893. London: H. M. Pollet and Co.

Walker, B. L. (2008). The Lost Wolves of Japan. Seattle: University of Washington Press.

Walton, J. (1900). China and the Present Crisis, with Notes on a Visit to Japan and Korea. London: Sampson Low, Marson and Co.

Yirga, G., Leirs, H., De Iongh, H. H., Asmelash, T., Gebrehiwot, K., Deckers, J., et al. (2015). Spotted hyena (Crocuta crocuta) concentrate around urban waste dumps across Tigray, northern Ethiopia. Wildl. Res. 42, 563-569. doi: 10.1071/WR1 4228

Zalasiewicz, J., Waters, C. N., Williams, M., Barnosky, A. D., Cearreta, A., Crutzen, P., et al. (2015). When did the Anthropocene begin? A mid-twentieth century boundary level is stratigraphically optimal. Quat. Int. 383, 196-203. doi: 10.1016/j.quaint.2014.11.045
Conflict of Interest: The authors declare that the research was conducted in the absence of any commercial or financial relationships that could be construed as a potential conflict of interest.

Publisher's Note: All claims expressed in this article are solely those of the authors and do not necessarily represent those of their affiliated organizations, or those of the publisher, the editors and the reviewers. Any product that may be evaluated in this article, or claim that may be made by its manufacturer, is not guaranteed or endorsed by the publisher.

Copyright (c) 2021 Powell, Axmacher, Linnell and Durant. This is an open-access article distributed under the terms of the Creative Commons Attribution License (CC $B Y)$. The use, distribution or reproduction in other forums is permitted, provided the original author(s) and the copyright owner(s) are credited and that the original publication in this journal is cited, in accordance with accepted academic practice. No use, distribution or reproduction is permitted which does not comply with these terms. 